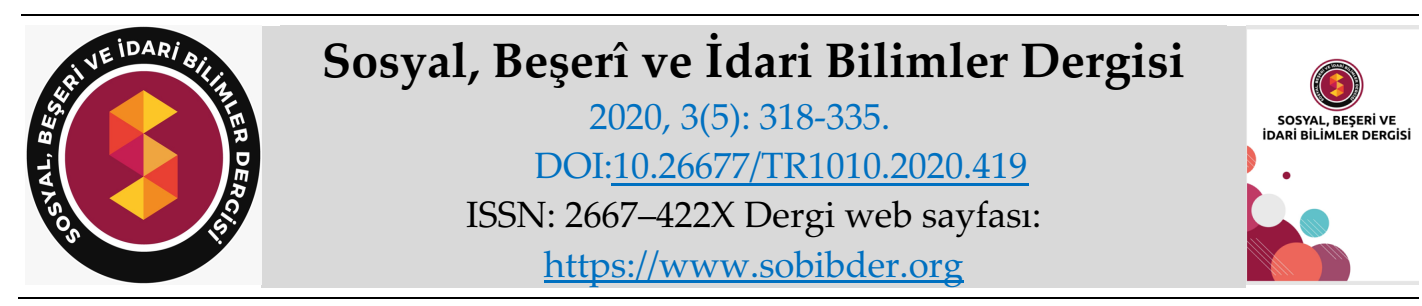

ARASTIRMA MAKALESI

\title{
Otel İşletmelerinde Gıda İsrafını Önlemeye Yönelik Turuncu Bayrak Uygulaması Üzerine Bir Araştırma
}

Derya ÇETINOĞLU, Doktora Öğrencisi, Ankara Hacı Bayram Veli Üniversitesi, Lisansüstü Eğitim Enstitüsü, Ankara, e-posta: derya.cetinoglu@hbv.edu.tr ORCID: https://orcid.org/0000-0001-7903-987X

Prof. Dr. Kurban ÜNLÜÖNEN, Ankara Hacı Bayram Veli Üniversitesi, Turizm Fakültesi, Ankara, e-posta: kurban.unluonen@hbv.edu.tr ORCID: https://orcid.org/0000-0002-4191-9019

\section{Öz}

İsraf sorunu, tüm ülkelerde olduğu gibi Türkiye'de de önemli görülmüş olup, bunun önüne geçebilmek için çeşitli kampanyalar, projeler, sertifikasyon programları ve uygulamalar geliştirilmiştir. Bu uygulamalardan biri olan turuncu bayrak uygulaması gıda israfının önüne geçebilmek ve gıdayı koruyabilmek için geliştirilmiş bir uygulamadır. Bu çalışmanın amacı, turuncu bayrak uygulamasının gıda israfı konusunda ne kadar etkili olduğunu ve turuncu bayrak uygulamasına sahip olan otellere sağladığı faydaları ortaya çıkarmaktır. Bu amacı gerçekleştirmek için nitel araştırma yöntemlerinden görüşme tekniği kullanılarak turuncu bayrak uygulamasına sahip otel yöneticileri ile mülakat yapılmıştır. Turuncu bayrak uygulamasına sahip otellerin gıda israfında önemli bir azalma olduğu ve müşteriler gözünde de tercih edilebilir olma sonucuna ulaşılmıştır. Turuncu bayrak uygulamasına sahip otel personellerin bu konuda daha duyarlı olduğu sonucu elde edilmiştir.

Anahtar Kelimeler: İsraf, Gıda İsrafı, Turuncu Bayrak.

Makale Gönderme Tarihi: 18.03.2020

Makale Kabul Tarihi: 04.05.2020

\section{Önerilen Atıf:}

Çetinoğlu, D. ve Ünlüönen, K. (2020). Otel İşletmelerinde Gıda İsrafını Önlemeye Yönelik Turuncu Bayrak Uygulaması Üzerine Bir Araştırma, Sosyal, Beşeri ve İdari Bilimler Dergisi, 3(5): 318-335.

C 2020 Sosyal, Beşerî ve İdari Bilimler Dergisi. 


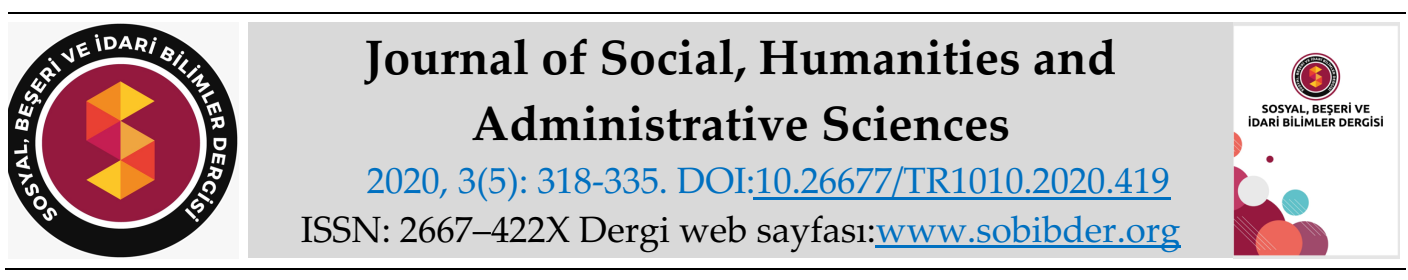

\title{
$\underline{\text { RESEARCH PAPER }}$
}

\section{A Research About Orange Flag to Avoid Hotels from Wasting Food}

Derya ÇETINOĞLU, Ph.D. Student, Ankara Hacı Bayram Veli University, Graduate Education Institute, Ankara, e-mail: derya.cetinoglu@hbv.edu.tr ORCID: https://orcid.org/0000-0001-7903-987X

Prof. Dr. Kurban ÜNLÜÖNEN, Ankara Hacı Bayram Veli University, Faculty of Tourism, Ankara, e-mail:kurban.unluonen@hbv.edu.tr ORCID: https://orcid.org/0000-0002-4191-9019

\begin{abstract}
Thus, some campaigns, certificate programs and projects are held in Turkey to avoid wasting of foods and resources. Orange flag program is one of them to decrease food wasting. The purpose of this paper is to investigate the success of orange flag program and to clarify benefits of it within hotels. In order to do that, interviews are held with hotel managers. As a result, it is seen that hotels with orange flag program have significant decrease about food wasting and also, they benefit by more interest from customers to prefer these hotels. It is concluded that the hotel staff with orange flag application are more sensitive in this regard.
\end{abstract}

Keywords: Wasting, Food Waste, Orange Flag.

Received: 18.03 .2020

Accepted: 04.05.2020

\section{Suggested Citation:}

Çetinoğlu, D. and Ünlüönen, K. (2020). A Research About Orange Flag to Avoid Hotels from Wasting Food, Journal of Social, Humanities and Administrative Sciences, 3(5): 318-335.

(c) 2020 Sosyal, Beşerî ve İdari Bilimler Dergisi. 


\section{GİRIŞ}

Tüketim kavramı her ne kadar maddi anlamda algılansa da aslında tüketimin yalnızca maddi boyutlarla sınırlandırılacak bir kavram olduğunu söylemek yanlış olacaktır. Tüm insanlığın sahip olduğu sosyal, kültürel ve manevi değerlerin de maddeleştirilerek giderek tüketime hazırlanması söz konusudur. Somut açıdan bakıldığında tüketim, para vererek karşılı̆̆ında herhangi bir şeyi almak anlamına gelmekteyken, soyut açıdan ise toplumunun en büyük sorunları arasındadır (Coşkun, 2012: 844). İnsanoğlu doğayı yok etmekte gelecek nesilleri düşünmeden hareket etmektedir. Tüm sektörlerde ve alanlarda kendini gösteren bilinçsiz tüketim kavramı giderek daha geniş alanlara yayılmaktadır. Bilinçsiz tüketim kullanımı israf kavramını da beraberinde getirmiştir. Özellikle israfın en çok görüldüğü sektör ve alanların başında gida (yiyecek-içecek), konaklama, giyim, teknoloji, turizm, iletişim, medya, vb. birçok alan örnek verilebilir (Akkoç, 2017: 583).

Dünyada her gün 13 milyon ton gida çöpe atılmakta bunun yanında 5 milyon litre boşa su harcanmakta 1,5 milyon ton sera gazı atmosfere salınmaktadır (http://turuncubayrak.org/). Gıda israfı özellikle hizmet sektörü başta olmak üzere birçok alanda önemli bir sorun teşkil etmektedir. Turizm gibi hizmet odaklı varlığını sürdüren bir sektörün alt boyutları olan konaklama, yiyecekiçecek, ulaştırma, rekreasyon vb. alanların hizmet sektörünün gıda israfında ilk sıralarda olduğunu söylemek yanlış olmayacaktır. Dünyada turizm hareketine katılan kişi sayısı 2019 yılında 1. 5 milyardır (UNWTO, 2019). Tüm bu verilere bakıldığı zaman dünyanın giderek yaşanılamaz bir yer olduğu sonucuna varılmaktadır (http://turuncubayrak.org/). Hizmet işletmeleri tüketiciye gelirlerinde harcaması gerektiğinden daha fazlasına özendirmekte ve onları bu olaya bağımlı hale gelmelerini sağlamaktadır. Lüks ihtiyaç olma özelliğinden çıkan turizm olgusunun artık çoğu ailenin katıldığı bir olgu olmasından doğan gösterişli tüketimin her geçen yıl artması yapay ihtiyaçların ortaya çıkmasına sebep olmuştur. Tüm bu durumlardan ortaya çıkan ve geri dönüşümü zor olan atık, israf, çevre ve doğa sorunları, doğal, yapay var olan kaynakların yok olmasına ve en önemlisi de insan yaşamının tehlikeye atılmasına sebep olmaktadır.

İsraf çeşitleri arasında en çok dikkat çeken gıda israfı tüm dünya ülkeleri adına önemli bir sorun teşkil etmektedir. Özellikle gelişmiş ülkeler bu sorunun baş aktörleri arasında gösterilmektedir. Ekonomik refahın ve yaşam kalitesinin artması, dışarda yemek yeme alışkanlığının popüler olması, kadınların iş yaşamlarında bulunmaları gibi birçok neden doğrultusunda insanların ev dışında yemek yeme alışkanlığını üzerinde etkili olmuştur. Gıda israfı konusunda yapılan çalışmaların daha çok restoran işletmeleri üzerine yapıldığı görülmektedir. Restoran işletmelerinde gıda atığının önüne geçebilmek için, gıda tedarik zinciri boyunca gıda atıklarına neden olan faktörlerin neler olduğunu belirlemek ilk aşamayı oluşturmaktadır. Daha sonra gıda atıklarının önlenmesi ve yönetilmesi için en uygun yöntemin ortaya çıarılması, son olarak da seçilen en uygun yöntemin uygulanması önerilmektedir (Papargyropoulou, Lozano, Steinberger, Wright ve Bin Ujang, 2014: 106). Aschemann-Witzel, De Hooge, Amani, Bech-Larsen ve Oostindjer (2015: 6459)'de gıda israfının önüne geçebilmek adına üzerinde durdukları en önemli konunun gida etiketleri üzerindeki tarih sıralamasına dikkat edilmesi gerektiğidir. Buradan çıkarılacak sonuç satın alınan ürünün depoya giriş tarihidir. "İlk giren ilk çıkar" düşüncesiyle hareket edilmesi gerektiğidir. Bu düşünce yalnızca işletmelerde değil hane halkının da uygulayabileceği bir düşüncedir.

Konaklama işletmeleri de restoran işletmeleri gibi gıda israfı gibi önemli bir sorunla karşı karşıya kalmıştır. Konaklama işletmelerinde gıda israfı çeşitli nedenlere dayanmaktadır. Bunlardan ilki gıdaların depolama kayıpları, yanlış depolanmalarıdır. İkinci olarak ise ürünü ortaya çıkarırken kullanmış olduğumuz sebze veya meyvelerin hazırlık aşamasında meydana gelen kayıplardır. 
Üçüncü aşamada ise, yiyeceklerin servis edildikten sonra tabakta kalan artıklardan oluşan kayıplardır. Son olarak ise, hazırlanmış ancak servis edilmeyen yiyeceklerden kaynaklanan atıklardır (Massow ve McAdams, 2015: 439). Konaklama işletmelerinde oluşan her türlü gıda atığı işletmeye gider kalemi olarak yazılmaktadır. Bunun önüne geçebilmek adına işletmeler gıda israfını önleyici olan uygulamaları bünyelerine almakta veya adapte etmek zorunda kalmışlardır. Bunlardan biri olan turuncu bayrak uygulaması konaklama, restoran ve diğer işletmelerde oluşan gıda atıklarının azaltılması adına geliştirilmiş bir sertifikasyon programıdır. Bu gibi uygulamaları işletmelerinde uygulayanlarına ne derece katkı sağladığını araştırılmak amacıyla bu çalışma gerçekleştirilmiştir.

\section{KAVRAMSAL ÇERÇEVE}

\section{İsraf Kavramı}

İsraf sadece dini alanda yapılan çalışmalarda değil, birçok alanda da kullanılmaya başlanmış hem kavram hem de konu olarak ortaya çımmaktadır. Türk dil kurumu Türkçe sözlügünde israf kavramı, gereksiz yere harcanan her türlü maddi ve manevi olguları ifade etmek olarak tanımlanmaktır (TDK, 2019). İsraf Arapça kökenli bir kelimedir. İsraf İslam dininde "her türlü sınırı aşmak" olarak ifade edilmektedir. Bireyin sahip olduğu her türlü maddi manevi olguyu gereksiz bir şekilde harcaması onun "müsrif" olarak tanımlanmasına sebep olmaktadır (Yıldırım, 2019: 43).

Bir başka tanıma göre israf, "inanç ve amelde dinin ve aklın uygun görmediği şekilde hareket etmek, ifrat ve tefrite düşmek", daha özel anlamı ile de "sahip olunan mal ya da olanakları yasal olmayan amaçlar için harcamak, ölçülü olmamak, haddi aşmak, savurganlık yapmak" anlamına gelmektedir. Yani israf, ölçülü olma ve orta yolu bulma anlamına gelen iktisat kavramıla zıt anlama sahiptir (Özdal, 2015: 3).

İsraf bir başka bakış açısıyla, yaygın ve bulaşıcı bir hastalık olarak görülmektedir. İsraf nedeniyle bireylerin ve toplumların yapıları olumsuz yönde etkilenmekte ve bu yüzden bireyler ve toplumlar ağır bedel ödemek zorunda kalmaktadırlar. İslam, israf olarak nitelendirilen savurganlıkların nicelik ve nitelikleriyle birlikte israf nedenlerini ve sonuçlarını tespit edilmesini sağlayarak farklı çözümler sunmaktadır. İsraf özellikle tüketim toplumunun en önemli sorunlarından biri konumundadır (Kayhan, 2006: 152-153). İsraf, bir ürün veya eşyayı faydalılık işlevinden çıkararak, lüzumsuz tüketim ile alanının dışına atmaktır (Martı, 2010: 143). İsraf kavramını yalnızca gıda, mal-mülk ve maddi durumlarla sınırlı olduğunu düşünmek, bu kavramın anlamını daraltmaktadır. İsraf kavramının sınırlarını daha kapsamlı şekilde maddîmanevi her türlü nimetin amacının dışında kullanılması, gereksiz şekilde sarf edilmesi ve savurganlık olarak değerlendirilmektedir. Gereksiz yere musluklardan akıtılan su, amaçsızca yakılan elektrik ve enerji sarfiyatı israf olduğu gibi, insanların zamanını boşa harcaması ve sağlıklarına zarar verecek davranışlar sergilemeleri de bir tür israf olarak nitelendirilmektedir (Sancakl1, 2013: 47-48).

İsrafın bugüne kadar "gıda atığı", "gıda israfı" veya "gıda" konusunda kabul edilmiş tanımlamaları bulunmamaktadır. Daha çok bir ürünün besin değerinin azalması, azalan tat, doku ve renkte gözle görülen ve istenmeyen değişmeler ya da ağırlığındaki azalma veya hacim ile ölçülen nicelik gibi unsurlarla da açılanabilmektedir. Gıda israfı, üretimindeki verilen firelerdeki kayıpları ve tüketim faaliyetinden sonra arda kalan kısımlardan oluşmaktadır. Aslında bakıldığı zaman, atık ve fire kavramı, aynı anlamlara sahip gibi görünebilmektedir (Erik, 2019: 4). Atık ve fire kavramları arasındaki farklılıklardan bir tanesi atıklar yani israf edilen maddelerin üretim zincirinde tekrar geri dönüştürülüp kullanılmasıdır. Firelerde böyle bir 
durum söz konusu değildir ve herhangi bir ekonomik değere de sahip değildirler (Doğdubay, 2006: 92). Tüm ülkelerde israf edilen maddeler arasında ilk sırada yer alan gıda israfı, öneminin anlaşılması üzerine ciddi ölçüde geri dönüşüm çalışmaları sayesinde ülkelerin ekonomisine önemli bir katkı sağlamaktadır (Bolayır ve Ergülen, 2017:2103). Bu olgu turizm sektörünün içerisinde yer alan konaklama ve yiyecek içecek hizmeti sunan işletmelerin de üzerinde önemle durduğu noktadır. Diğer bir ifadeyle işletmelerin gıda üzerinde oluşan kayıpları en aza indirmek ve ardından maliyetleri en düşük seviyede tutma çabalarının altında israfı önleme düşünceleri yatmaktadır (Doğdubay ve Sarığlan, 2010:107). Bu düşünceye kapılmaktaki neden ise yiyecek içecek hizmeti sunan restoranlar ya da konaklama işletmelerinin ekonomik olarak daha sağlıklı sürdürülebilir bir işletme olma çabaları olarak ifade edilebilir (Çam, 2009:502).

İsraf denilince akla sadece yiyecek- içecek(gıda) israfı gelmemeli bunun yanında enerji, su, giyim ve kağıt israfı da gelmelidir. Aslında insanlar sadece gıda israfı konusunda bilinçli olmanın yanında tüm israf olan olgular hakkında dikkat etmeli ve bilinçli davranmalıdırlar.

\section{Gıda İsrafı}

7,5 milyarı geçen dünya nüfusunun en büyük problemlerinden bir tanesi de açlık ve yetersiz beslenmedir. Yılda 870 milyon kişinin yeterli beslenemediği ve milyonlarca insanın yetersiz beslenme ve açlık sebebiyle yaşamını yitirdiği dünyada, gıda israfı önemli boyutlara ulaşmıştır (TMO, 2019).

Her yıl insan ihtiyacı için üretilen yiyeceklerin büyük miktarı farklı sebeplerden dolayı kaybedilir veya israf edilir. Bu durum özellikle gelişmiş ülkelerde fazladır ve bulaşıcı bir hastalık gibi tüm dünyayı sarmaya başlamışır. Bu yayılmanın sebebi olarak gelir artışı, tüketilecek ürün sayısındaki artış ve gösteriş odaklı pazarlama uygulamaları olarak gösterilmektedir.

“Dünyadaki herkesi beslemek için yeterli derecede yiyecek olmasına rağmen dünya üzerindeki 815 milyon insan gıdaya ulaşım sağlayamamaktadır. Dünyanın karşı karşıya kaldığı en büyük zorluklardan biri, 2050 yılına kadar yaklaşık 10 milyara ulaşması beklenen artan küresel nüfusun, beslenme ihtiyaçlarını karşılamak için yeterli yiyeceğin olmasını sağlayamama durumudur. 2050 yılında iki milyar insan daha beslemek için, gıda üretiminin küresel olarak \%50 oranında artması gerekmektedir. Gıda güvenliği, tüm yetersiz beslenme biçimlerine, kü̧̈ük ölçekli gıda üreticilerinin üretkenlik ve gelirlerine, gıda üretim sistemlerinin dayanıklılı̆̆ına, biyolojik çeşitliliğin ve genetik kaynakların sürdürülebilir kullanımına bütünsel bir yaklaşım gerektiren karmaşık bir durumdur" (https://tuketici.ticaret.gov.tr/).

Toplumlarda yeme-içme özellikle de ekmek konusunda önemli ölçüde israf yapılmaktadır. Bunun sebebi ise hane halkı olarak gösterilmektedir. Hane halkı yiyecek-içecek yönetimi konusunda yeteri kadar eğitilmedikleri ve bu konuda bilgileri olmadıkları için israf kaçınılmaz bir hal almıştır. Bunun önüne geçecek olan yine insanoğlundur.

Dünyada her 3 tabaktan birinin çöpe gittiği ve her 1 dakikada 3 çocuğun açlıktan öldüğü ve israf edilen gıdanın yüzde 60'ının yeniden kazanılabileceği düşünüldügünde durumun ciddiyeti daha çok kendini göstermektedir. Her ne kadar bu istatistikler tüm ülkeleri ve uluslararası kuruluşları önlem almaya yöneltmiş ve bu önlemler sonucunda birtakım olumlu sonuçlar alınmaya başlanmış olunsa da, eğer bu önlemlerin hızı ve yaygınlığı eş zamanlı olmazsa iklim, su, toprak, çevrenin yanı sıra biyo-çeşitlilik de risk altında olacaktır. Bu da beraberinde dünyanın gıda arzında sürdürülebilirlik tehlikesi ile karşı karşıya kalması sorununu getirecektir (Dölekoğlu vd., 2014: 172). 
Gıda israfı sorunu, tüm dünya genelinde önlenmesi ve çözüme ulaştırılması için çaba harcanan açlık, iklim değişikliği gibi diğer güncel sorunların arasına girmiştir. Özellikle de gıda israfı içerisinde büyük bölüme sahip olan ekmek israfı önemli toplumsal sorunlar arasında boy göstermektedir. Ekmeğin çöpe atılmasındaki en önemli sebep ekmeğin bayatlamasından kaynaklanmaktadır. Ekmek israfı en çok evlerde tüketiciler tarafından yapılmaktadır. Hanelerdeki kişi sayısı arttıkça buna paralel olarak ekmek alım miktarı da artmaktadır. Aile bir bütün olarak düşünüldüğü için hane içinde bulunan çocuk, genç ve yaşlıların istekleri doğrultusunda ekmek alımı yapılmamakta kişi sayısı bağlamında ekmek alınmaktadır. Ailelerde ekmek israfının kişi sayısı ile doğru orantılı olduğu anlaşılmaktadır.

Hane halkının yanı sıra üretici açısından da -ekmeğe olan tüketici talebi ortalama olarak belli olsa da- ekmek üretim işletmeleri fazla üretim yapabilmektedirler. Bu durum da kalan ekmeğin israfı anlamına gelmektedir (Akın, 2010: 158). Ekmek israfının büyük ekonomik kayıplara sebebiyet verdiği düşünüldügünnde bu israfın önüne geçmek için bir şeyler yapılması gerektiği ortadadır. Ekmek israfını önlemedeki en etkin yöntem; ekmeğin ihtiyaç kadar üretilip bayatlamadan tüketilmesidir. Ekmek üretim tekniklerini bilme ve uygulama, doğru ambalaj ile ambalajlama, arz ve talep dengesini gözeterek ekmek üretmek ekmek israfını önlemede dikkat edilmesi gereken konulardır. İstenmediği ve gerekli hassasiyetin gösterilmesi halinde bayatlamış ekmeklerin de çöpe atılmadan değerlendirilmesi mümkündür (Mete, 2017: 1).

Ülkelerin gelişmişlik düzeyi arttıkça buna paralel olarak her alanda yaşanan israf sorunu, gıda israfında da kendini göstermektedir. Gıda israfının bu denli büyümesi sadece bir veya iki nedene bağlanmamalıdır. Modern gıda sistemleri, sanayileşme, ekonomik büyüme, kentleşme, küreselleşme, kültür ve tüketici davranışı gibi birçok faktör gıda israfına neden olmaktadır (İlyasov, 2017: 42). Bu bilgiler ışı̆̆ında çı̆̆ gibi büyüyen israfa ülke genelinde dikkat çekmek ve önlemek amacıyla kurulan Gıda İsrafını Önleme ve Bilinçlendirme Platformu, her alanda etkinlikler yapmak hedefiyle çalışmalarına başlamıştır. Geliştirilen program ile turizm sektörü içerisinde yer alan konaklama ve yiyecek-içecek işletmeleri, eğitim kurumları, hastaneler ve askeri birimler başta olmak üzere ülke geneline yayılması amaçlanan bir proje geliştirilmiştir. Öncelikli olarak da israfın en çok yaşandığı turizm sektörü seçilmiştir. Özellikle açık büfe ve her şey dahil sistemlerde yaşanan israfın önüne geçmek, işletme çalışanlarını ve tüketicileri bilinçlendirmek adına oluşturulan kriterlerin tamamı Turuncu Bayrak adı altında bir araya getirilmiştir. Tüm bu bilgiler ışığında gıda israfına sessiz kalmak mümkün değildir. Gıda israfını önlemek amacıyla oluşturulan en önemli uygulamalarda bir tanesi de turuncu bayrak uygulamasidır (http://turuncubayrak.org/).

Bilim dünyasında gıda israfı konusunda araştırma sayısında bir artış olmuştur. Araştırma konuları genellikle gıda israfının çevresel ve etik problemlere, verimsiz kaynak kullanımına, ekonomik bozulmalar üzerinde yoğunlaşmıştır. Çoğu ülke ve uluslararası kuruluş, gıda israfının neden olduğu sosyal adaletsizliği, çevre kirliliği, ekolojik denge bozulmaları, iklim değişiklikleri, kötü kaynak kullanımı gibi sonuçlarının önüne geçmek için gıda israfını önleme çalışmaları yapmaktadır (Gjerris ve Gaiani, 2013: 6).

21. yy'ın en önemli konularından biri olan ve tüm insanlığı ilgilendiren gıda atığı konusu ile ilgili akademik yazın incelendiğinde birçok araştırmanın yapıldığı gözlemlenmektedir. Özellikle yiyecek- içecek ve konaklama işletmelerinde gıda israfı ile ilgili yapılan çalışmalar göze çarpmaktadır. Çalışmaların bu işletmeler üzerinde yoğunlaşmasının sebebi olarak da hizmet odaklı ve tüketici odaklı olmaları gösterilmektedir. Konaklama sektöründe gıda israfı ile ilgili yapılan çalışmalara bakıldığında örneğin, İlyasov (2017: 118) yaptığı araştırmada açık büfe servis sisteminde misafirlerin gıda israfı tutumlarını ortaya koymayı amaçlamıştır. Yapılan araştırmada “açı büfe sunumu yapan beş yıldızlı otellerde konaklayan Türk misafirlerin yüksek 
sayılabilecek düzeyde gıda israfı tutumu sergilediği, misafirlerin demografik karakteristikleri ve kişisel özellikleri ile gıda israfı tutumları arasında anlamlı ilişkiler olduğu" sonucuna varılmıştır.

Bir başka çalışmada, Özdemir (2018: 85) “beş yıldızlı zincir otellerin mevcut gıda atık yönetimi politikalarını, ilgili planlarını ve geleceğe yönelik projeleri analiz etmek ve Türkiye genelindeki mevcut uygulamaları küresel uygulamalarla karşılaştırarak eksiklerini belirlemek ve etkili bir gıda israf yönetimi için somut öneriler sunmak" olarak amaçlamıştır. Yazar "gıda atıklarına ilişkin alınan tüm kurumsal önlemlere rağmen çoğunlukla bilinçsiz müşteri tutumlarından kaynaklanan yüksek miktarda gıda atığı olduğuna dair" sonuçları ortaya koymuştur.

Yıldırım (2019) çalışmanın temelini helal konseptli otel işletmelerinin israfı önleme çalışmalarının neler olduğunun değerlendirilmesi ve helal konseptli otel çalışanlarının israfa karşı yaklaşımlarının araştırılması üzerine oluşturmuştur. Araştırmada "israfı önlemenin amacı", "israf önleme farkındalığını oluşturma çalışmaları" ve "israf önlemeye yönelik uygulamalar" olmak üzere 3 faktörde toplandığı sonucuna varılmıştır. Bunun yanında diğer bir sonuç da helal konseptli otellerin israf önleme çalışmalarının genel olarak çalışanlar tarafından yüksek düzeyde olduğudur.

Konuyu yiyecek-içecek personelinin gıda israfı hakkında bilgi, görüş ve davranışları bağlamında ele alan Kurt (2019) aşçıların gıda güvenliğine yönelik bilgi düzeylerinin yetersiz olduğu ve bu durumun gıda israfına yönelik davranışlarını olumsuz yönde etkilediğini ayrıca çalışmaya katılan aşçıların gıda israfı konusunun çok önemli olduğunu, istemeden de olsa gıda israfı yaptıklarını belirtmişlerdir ancak artan gıdalarla ilgili hiçbir çalışma yapmadıkları sonuçlarına ulaşmıştır.

Konaklama işletmelerinde özellikle otellerde gıda israfının önlenmesi veya en aza indirilmesi için stratejiler ve uygulamalar geliştirilmelidir. Öncelikle planlama dâhilinde otel işletmelerinde gıda israfına nelerin sebep olduğu ortaya çıkarılmalıdır. Gıda israfını önlemeye yönelik olan turuncu bayrak uygulaması konaklama işletmeleri ve yiyecek içecek işletmeleri için önem arz etmektedir. Turuncu bayrak uygulaması, israfın önlenmesi ve gıdanın korunması amaciyla yapılan çalışmalara doğrudan katkı sağlamak, bu konuda farkındalık oluşturmak için geliştirilen bir sistem bütünüdür. Bu sistem, gıdanın üretiminden işlenmesine, depolanmasından satışı ve tüketimine kadar gıda ile ilgili her türlü hizmeti kapsamaktadır (http://turuncubayrak.org/).

Dünya genelinde her geçen gün artan nüfusla orantılı olarak, gıda israfı da artış göstermektedir. Yeryüzünde herkese yetecek miktarda yiyecek üretilmesine rağmen dengesiz dağılım nedeniyle bazı bölgelerde israfla karşılaşılırken bazı bölgelerde açlık ve ölüm boy göstermektedir. Yapılan araştırmalar, 2050 yılında 10 milyara ulaşacağı öngörülen dünya nüfusunu beslemek için gıda üretiminin yüzde 60-70 artması gerektiğini göstermektedir. Durum böyleyken her yıl dünyada üretilen 4,5 milyar ton gıdanın 1,3 milyar tonu tüketiciye ulaşmadan çöpe gitmektedir. Çöpe atılan bu gıdaların hem çevresel hem sosyal açıdan çok ciddi zararlara neden olduğu herkes tarafından bilinmektedir. İklim değişikliklerinin bir nedeni olan karbon salınımının artmasına bir sebep de atılan bu gıdaların çok büyük miktarlara ulaşması olarak gösterilebilir (https://tuketici.ticaret.gov.tr/). Gıda israfının çevresel zararlarının yanında bir diğer önemli boyutu da sosyal açıdandır ki; dünya genelinde israf ve açlıktan ölüm oranları neredeyse başa baş gitmektedir. Küresel olarak bakıldığında dünya genelinde üretilen tüm gıdaların 1/3'ünden fazlası israf edilerek çöpe atılmaktadır. İsraf edilen bu gıdaların yıllık değeri 1 trilyon dolar olup, 1,3 milyar ton ağırlığındadır. Ortalama bir milyar aç insan, ABD, İngiltere ve Avrupa'da israf edilen gıdaların dörtte birinden daha az bir miktarıyla beslenebilirken, yapılan araştırmalar israfın 4 'te 1 azaltılması halinde bile dünyada 815 milyon kişiye gıda ulaşabileceğini göstermektedir. Bu ciddi rakamlar, ülkeleri adeta israfa karşı birlik olmak, plan ve projeler üretmek için zorlamaktadır (https://tuketici.ticaret.gov.tr/). 
Türkiye'ye bakıldığında durumun hiç de iç açıcı olmadığı görülmektedir. Gıda israfının 214 milyar liraya ulaştığı Türkiye'de her yıl üretilen 49 milyon ton sebze ve meyvenin önemli bir miktarı çöpe gitmektedir. TÜBİTAK'ın hesaplarına göre yıllık kayıp miktarı yaklaşık 12 milyon tondur (Gümüş, 2014: 49).

Bu bilgiler 1şığında çığ gibi büyüyen israfa ülke genelinde dikkat çekmek ve önlemek amacıyla kurulan gıda israfını önleme ve bilinçlendirme platformu, her alanda etkinlikler yapmak hedefiyle çalışmalarına başlamıştır. Geliştirilen program ile turizm işletmeleri, eğitim kurumları, hastaneler, askeri birimler başta olmak üzere ülke geneline yayılması amaçlanan bir proje geliştirilmiştir. Öncelikli olarak da israfın en çok yaşandığı turizm sektörü seçilmiştir. Özellikle açık büfe ve her şey dâhil sistemlerde yaşanan israfın önüne geçmek, işletme çalışanlarını ve tüketicileri bilinçlendirmek adına oluşturulan kriterlerin tamamı turuncu bayrak adı altında bir araya getirilmiştir. Turuncu bayrak "afiyet olsun israf olmasın" sloganıyla yola çıkarak ilk olarak oteller ile işbirliği içerisine girmiştir. Bu süreci belediyeler, alışveriş merkezleri, hastaneler, eğitim kurumları, restoranlar ve daha birçok kuruluş ile devam ettirmek için işbirliği görüşmelerine devam etmektedir. Turuncu bayrağın başlıca amacı israf konusundaki bilinç düzeyini geniş alanlara yayarak; gıda israfını \%70 oranında azaltmak ve kaynakları önemli ölçüde koruyarak gelecek nesillere yaşanabilir bir dünya bırakmaktır. Turuncu bayrak uygulaması hedefleri arasında, gelecek nesillere yaşanabilir bir gezegen bırakmak, sürdürülebilir bir yaşam oluşturmak, israf konusunda bilgilendirmeler yaparak toplumdaki farkındalık düzeyini arttırmak, çocukların gelecekte farkındalık sahibi bireyler olmalarını sağlamak, gıda israfını \%70 oranında azaltmak, kaynakları korumak, ülke ekonomisine katkıda bulunmak, uluslararası alanda öncülük ederek dünya çapında gıda dostu bir akım oluşturmaktır (http://turuncubayrak.org/). Turuncu bayrak uygulamasının ortaya çıkmasında, hizmet işletmelerindeki meydana gıda israfı ve bu israfın hiçbir şekilde geri dönüşümünün sağlanmamasıdır. Turuncu bayrak uygulaması işletmelerde ortaya çıkacak olan gıda israfını azaltacağı düşünülerek faaliyete geçirilmiş bir sertifikasyon programıdır.

Turuncu bayrak uygulamasının (Tuba) hedef kitlesini, otel, restoran, kafe, market, gida toptancisı, AVM, gida üretim, işleme, paketleme ve depolama tesisleri vb.) veya kurumlar (bakanlıklar, taşra teşkilatları, belediyeler, okullar, kamuya bağlı yurtlar veya misafirhaneler, STK'lar, oda, borsa ve birlikler, üniversiteler vb.), Türkiye'de ve dünyada gıda israfının önlenmesine katkı sağlayacak toplumun tüm kesimleri oluşturmaktadır. Gıda israfını önlemek adına işletmeler ile birlikte hareket eden turuncu bayrak uygulaması Kültür ve Turizm Bakanlığı'ndan Turizm İşletme Belgesi almış tesisler, gerekli kriterleri sağladıkları takdirde "Turuncu Bayrak Belgesi" alabilirler. İşletmelerin yerine getirmesi gereken turuncu bayrak uygulaması altında 14 ana başlık altında 45 adet kriter bulunmaktadır (http://turuncubayrak.org/).

\section{YÖNTEM}

Konunun araştırılma amacına uygun olarak nitel araştırma yöntemi kullanılmıştır. Nitel araştırma, "gözlem, görüşme ve doküman analizi gibi nitel veri toplama yöntemlerinin kullanıldığı, algıların ve olayların doğal ortamda gerçekçi ve bütüncül bir biçimde ortaya konmasına yönelik nitel bir sürecin izlendiği araştırma" olarak tanımlanabilir (Yıldırım ve Şimşek, 2016: 41). Bir başka tanımlamaya göre nitel bir araştırma, bireylerin davranışları ve motivasyonlarının altında yatan bilgilerin derinlemesine araştırıldığı ve çok değerli bilgilerin ortaya çıkarıldığı araştırmalar olarak tanımlanmaktadır (Güler vd., 2015: 39). Nitel araştırma; bireylerin yaşam tarzlarını, davranışlarını, öykülerini, örgütsel yapılarını, toplumsal değişmeyi, 
algıların ve olayların doğal ortamda gerçekçi ve bütüncül bir biçimde, yorumlayıcı bir yaklaşımla inceleyen bir yöntemdir (Karagöz, 2017: 565).

\section{Araştırma Problemi}

Gıda israfı tüm sektörlerde olduğu turizm sektöründe de önemli bir sorun haline gelmiştir. Özellikle konaklama ve yiyecek içecek işletmelerinde gıda israfı büyük bir sorun teşkil etmektedir. Konaklama ve yiyecek işletmelerinde gıda israfını önüne geçebilmek için birçok sertifikasyon bulunmaktadır. Turuncu bayrak uygulaması da konaklama ve restoranlarda gida israfının önüne geçebilmek adına verilen bir sertifikasyondur. Konaklama işletmelerinde ortaya gıda israfının rakamsal olarak ne kadar olduğu ve turuncu bayrak uygulamasının gıda israfını engelleme konusunda etkili olup olmadığı araştırmanın problemini oluşturmaktadır.

\section{Araştırmanın Amacı}

$\mathrm{Bu}$ araştırmanın temel amacı, konaklama işletmelerindeki gıda israfını \%70 oranında azaltmayı hedefleyen turuncu bayrak uygulamasının yöneticiler gözünde ne kadar etkili olduğunun çıarılmasındadır. Bu temel amaç doğrultusunda;

1. Turuncu bayrak uygulamasının daha çok bilinirliliğini arttırmak,

2. Otel yöneticilerinin özellikle gıda israfının önüne geçmesi gerektiği hakkında bilgilendirmek ve israfı engellemek adına varsa diğer uygulamalardan da haberdar etmek,

3. Bilinçli müşteri profili oluşturarak israfa karşı sürdürülebilir bir tutum göstermek,

Bu alt amaçlar dışında, araştırılan konunun sürdürülebilirlik ve gıda israfı konusunda yapılan çalışmalara yeni bir boyut kazandırılmasını sağlamak ve bu konu hakkında araştırma yapacak olan araştırmacılara öneriler sunmak ve farklı bakış açıları yakalamalarını sağlamak da amaçlanmıştır.

\section{Araştırmanın Önemi}

Atık, israf ve sürdürülebilirlik konusu ile ilgili çalışmalar incelendiğinde literatüre farklı birçok çalışmanın kazandırıldığı görülmüştür. Ancak bu çalışmada atık konusu ile ilgili literatüre yeni kazandırılmaya çalışılan turuncu bayrak uygulaması hem otel işletmelerinin gıda israfı konusunda farkındalık kazanması ve sürdürülebilirlik ve çevreye duyarlılık açısından rekabet edilebilirliğini arttırması hem de tüketicilerin turuncu bayrak uygulaması ile ilgili farkındalık kazanarak farklı bir çalışma ortaya çıkarılmaya çalışılmıştır. Turuncu bayrak uygulaması literatüre kazandırılmaya çalışıldığı için güncelliğini korumakta ve çalışmayı önemli kılmaktadır.

Çalışmada nitel araştırma yönteminin kullanılmasındaki amaç belirlenen konu üzerinde derinlemesine bilgi alınmak istenmesinden kaynaklanmaktadır. Araştırmada görüşme tekniği kullanılmıştır. Literatür taraması sonucu yüz yüze görüşmede sorulabilecek sorular belirlenmiş ve turuncu bayrak sahibi otel yöneticileri ile görüşme gerçekleştirilmiştir. Yapılandırılmış görüşme formu; araştırmacı soruları önceden hazırlamıştır ve görüşme esnasında bu sorular dışında başka bir soru sormadan görüşmeyi sonlandırmayı amaçlamaktadır. Bu görüşme türünde esneklik bulunmamaktadır. Yapılandırılmış görüşmedeki amaç, görüşülen bireylerin verdikleri cevaplardan hangilerinin paralellik hangilerinin farklılık gösterdiğini ortaya çıkartarak karşılaştırma yapmaktır (Karasar, 2005: 5). Görüşme sonucunda elde edilen bulgular betimsel analiz yöntemi ile analiz edilmiştir. Betimsel analiz yönteminde, görüşülen ya da gözlemlenen 
bireylerin görüşlerini dikkat çekici bir hale getirmek için doğrudan alıntılara yer verilmektedir. Bu tür analizde amaç, elde edilen verilerin düzenlenmiş ve yorumlanmış bir biçimde okuyucuya sunulmaktadır. Bu amaçla elde edilen veriler, önce sistematik ve açık bir biçimde betimlenir (Yıldırım ve Şimşek, 2016: 239- 240).

Rasyonel sonuçlar ve genellemelere ulaşmaya yardımcı olmak için yeterli veri sağlayacak uygun bir örneklem büyüklüğü elde etmek önemlidir (Miles ve Huberman, 1994). Bu nedenle, çalışmanın amacını doğru bir şekilde sonuçlandırmak için bilgi bakımından zengin temsili bir örnek gerekmektedir. Bu araştırmada, olasılığa dayalı olmayan örnekleme yöntemlerinden biri olan kasti (kararsal) örnekleme yöntemi kullanılmıştır. Kasti örneklem tekniğinde, örneklemi oluşturan katılımcılar araştırmacının araştırma problemlerine cevap bulacağına inandığı kişilerden oluşmuştur. Başka bir deyişle, katılımcıların belirlenmesindeki ölçüt, araştırmacının yargısıdır (Altunışık vd., 2012: 10). Stratejik kararlar ile doğrudan bağlantısı olan ve rekabetçi sektörlerde faaliyet gösteren işletmelerde işletme sahibi, yönetici, finans müdürü gibi pozisyonlarda görev yapan otel yöneticileri ile görüşme yapılmıştır.

Tablo 1. Görüşme Soruları

1. Turuncu bayrak uygulamasindan nasil haberdar oldunuz? Turuncu bayrak uygulamasını alma hikâyeniz neydi?

2. Turuncu bayrak uygulaması alırken veya aldıktan sonra işletmenizde ne gibi sorunlarla karşılaştınız?

3. Turuncu bayrak uygulamasını aldıktan sonra işletmede ne gibi değişiklikler oldu?

4. İşletmenizde misafirlerinizin gıda atığına yönelik farkındalık oluşturmalarını sağlamak için neler yapıyorsunuz?

5. Turuncu bayrak uygulaması aldıktan sonra müşteri kitlenizde ne gibi değiş̧iklikler oldu?

6. Personelinizde gıda atığı konusunda duyarlılığı nasıl oluşturdunuz?

7. Personelinize gida israfı konusunda ne gibi etkinlikler yapıyorsunuz? Ne gibi eğitimler veriyorsunuz?

8. İşletmenizde gıda atığı olarak hangi ürün en çok çöpe gitmektedir? Turuncu bayrak uygulaması bunu ne ölçüde azaltmıştır? Örnek vererek açıklar mısınız?

9. Gelecekte gıda israfı ve diğer israf çeşitleri ile ilgili neler yapmayı planlıyorsunuz?

10. Gıda israfında farkındalık oluşturmak için ne gibi faaliyetlerde bulunuyorsunuz?

Çalışmada on sorudan oluşan yapılandırılmış görüşme formu kullanılmıştır. Çalışma kapsamında sorular turuncu bayrak uygulaması kriteriler dikkate alınarak oluşturulmuştur. Oluşturulan sorular alanında uzman olan iki araştırmacıya gösterilmiş olup araştırmacının görüşü alınarak soruların geçerliliği sağlanmıştır. Daha sonra hazırlanmış olan sorular turuncu bayrak uygulamasına sahip otel yöneticilerine yöneltilmiştir. Türkiye'de toplamda on beş otel turuncu bayrak uygulamasına sahiptir. Bu otellerin dokuzu Antalya, üçü Afyonkarahisar, İzmir, Muğla ve Rize de de birer tane bulunmaktadır. Çalışmanın geçerliliği araştırmacı tarafından sağlanmıştır. Araştırma kapsamında turuncu bayrak uygulaması almış olan on beş otel yöneticisi ile görüşme yapılmak istenmiştir. Ancak araştırmaya dâhil edilen otel yöneticilerinin bazıları yeni yöneticilik pozisyonuna geldikleri için görüşmeye sıcak bakmamışlarıdır ve araştırmaya dâhil edilmemişlerdir. Araştırma on bir otel yöneticisi dâhil edilerek gerçekleştirilmiştir. Araştırmaya dâhil edilen on bir otel yöneticisi ile yapılan görüşmeler 25- 30 dakika sürmüştür. Görüşme esnasında verilen bilgiler ses kayıt cihazı ile kaydedilmiş olup ayrıntılı bir şekilde tablolar haline getirilip raporlanmıştır. 
Çalışma kapsamında otel yöneticilerine şu sorular yöneltilmiştir. Alınan cevaplar tablolar haline getirilmiş olup bulgular kısmında ayrıntılı bir şekilde yer verilmiş ve analizleri sağlanmıştır.

Turuncu bayrak uygulamasına sahip on bir otel yöneticisinin farklı departmanlardan seçilmiş olması araştırmayı güçlü kılmıştır. İlk olarak görüşme kısmına geçmeden önce katılımcılara araştırma hakkında kısaca bilgi verilmiştir. Soruların içeriğinden ve anlaşılmayan kavram veya ifadelerden bahsedilmiştir. Tablo 1'de on adet görüşme sorusuna yer verilmiştir.

\section{BULGULAR}

\section{Otel Yöneticilerinin Demografik Özelliklerine İlişkin Bulgular}

Tablo 2'de otel yöneticilerine ait özellikler (medeni durum, yaş, eğitim durumu ve cinsiyet) ayrıntılı bir şekilde verilmiştir. Görüşme yapılan otel yöneticilerinin vermiş oldukları cevapların gizli kalacağı söylendiği için isimleri "Katılımcı 1, Katılımcı 2, Katılımcı 3 şeklinde" 1 den 11'e kadar verilen sayılarla kodlanmıştır. Kodlama sadece araştırmacının bilgisi dâhilin de karmaşık bir şekilde yapılmışır.

Tablo 2. Katılımcların Demografik Özellikleri

\begin{tabular}{lcccc}
\hline \multicolumn{1}{c}{ Katılımc1 } & Yaş & Cinsiyet & Medeni Durum & Eğitim Durumu \\
\hline 1.Katılımcı & 33 & Kadın & Bekar & Lisans \\
2.Katılımc1 & 33 & Erkek & Evli & Lisans \\
3.Katılımcı & 43 & Erkek & Evli & Lisans \\
4.Katılımcı & 31 & Erkek & Bekar & Lisans \\
5.Katılımc1 & 34 & Erkek & Bekar & Lisans \\
6.Katılımc1 & 29 & Kadın & Bekar & Lisans \\
7.Katılımc1 & 30 & Erkek & Evli & Lisans \\
8.Katılımcı & 28 & Kadın & Evli & Lisans \\
9.Katılımc1 & 43 & Erkek & Evli & Lisans \\
10.Katılımc1 & 45 & Kadın & Evli & Lisans \\
11.Katılımc1 & 43 & Erkek & Evli & Ön Lisans \\
\hline
\end{tabular}

Tablo 2' de 11 otel yöneticisine ait demografik bilgilere yer verilmiştir. Bu bilgiler doğrultusunda görüşme yapılan otel yöneticilerinin yaş aralığı 28-45 iken, yaş ortalamaları 35,6 olarak hesaplanmıştır. Katılımcılardan 7 katılımcı evli iken geri kalan 4 katılımcı ise bekârdır. Eğitim durumları ise 10 katılımcı lisans mezunu iken 1 katılımcı ön lisans mezunudur.

\section{Turuncu Bayrak Uygulamasına İlişkin Bulgular}

Araştırma kapsamında görüşme yapılan onbir otel yöneticisine turuncu bayrak uygulamasından nasıl haberdar olduklarını ve turuncu bayrak alma öykülerinin ne olduğu soruları yöneltilmiştir. Yapılan görüşmeler sonucunda alınan cevaplar analiz edilerek şu sonuçlara varılmıştır. Katılımcıların çoğundan alınan cevap doğrultusunda turuncu bayrak uygulamasından gıda dostu derneği tarafından bilgilendirilerek ve verdikleri eğitimler sayesinde haberdar olduklarını belirtmişlerdir. Turuncu bayrak uygulamasına sahip olma öyküleri ve buna ne için gerek duydukları sorulduğunda ise alınan cevaplar şunlar olmuştur;

Katılımcı 1, 2, 3 ve 4 "çalıştığımız oteller 4 büyük turizm tesisi ile hizmet vermektedir. Tesislerin büyük olması sebebiyle israfın çok oluşu yapılan anlaşma ile sektörde öncü olmak adına misafirlerin aşırı 
kullanımları üzerine farkındalık oluşturmak adına gıda israfinı azaltma çalışmaları yapmak için bu oluşumun içerisine dâhil olmuştur" cevaplarını vermişlerdir.

Katılımcı 5 "işletmemizin en çok restoran kısmında gider kaleminin olduğunu fark ettik ve gider kaleminin içerisinde de gıda atı̆̆ının olduğunu görünce buna bir dur demek için bu gibi bir uygulamanın hem işletmemiz açısından hem de misafirlerimizin açısından olumlu bir etkisi olacağını düşündük ve turuncu bayrak uygulamasın otelimizde uygulamaya karar verdik".

K9, K10 ve K11, "hem işletmenin imajını korumak hem de bilinçsiz gelen tüketiciden sıkıldığımız için bir nevi onları işletmeye çekmemek adına bu uygulamayı aldığımızı belirtebiliriz" diye yanıtlamışlardır.

Tüm bu cevaplardan çıkan sonuçlar 1şığında turuncu bayrak uygulamasının işletmelere sadece gıda israfını azaltmak gibi tek yönlü bir artısının olmadığını bunun yanında bilinçli tüketici profilini kendi bünyelerine çekebildiklerini ve işletmenin imajı açısından da bunun önemli olduğu vurgusu yapılabilmektedir.

\section{Turuncu Bayrak Uygulamasını İşletme Bünyesine Alırken ve Aldıktan Sonra Yaşanılan Sorunlara İlişkin Bulgular}

Bu başlık altında onbir otel yöneticisine "turuncu bayrak uygulamasını alırken ve aldıktan sonra bu süreci devam ettirirken ne gibi zorluklarla karşılaştıkları" sorusu yöneltilmiştir. Alınan cevaplar doğrultusunda bazı yöneticiler hiçbir sorunla karşılaşmadıklarını belirtirken bazı yöneticiler ise turuncu bayrak uygulamasına adapte olma sürecinde sıkıntı yaşadıklarını ve bunun devam ettirmenin de zor ve maliyetli bir iş olduğunu belirtmişlerdir.

K1, 2, 3 ve 4 "turuncu bayrak uygulamasını alırken bir zorluk yaşamadık düzenli ve sistemli bir şekilde uygulamayı devam ettirdiğimiz için sürecin ilerisinde de bir problem yaşamadık".

Katılımcı 7, "turuncu bayrak uygulamasını aldığınız zaman iş bitmiyor aldıktan sonra bunu birde devam ettirme süreci var ve sürekli bir kontrol mekanizması ile karşı karşıya olduğunuzu bilmek hem sizi yoruyor hem de başaramama korkusu motivasyonunuzu düşürebiliyor".

\section{Turuncu Bayrak Uygulaması Aldıktan Sonra İşletmelerde Yaşanan Değişikliklere İlişkin Bulgular}

Burada katılımcılara şu şekilde bir soru yöneltilmiştir "turuncu bayrak uygulamasını aldıktan sonra işletmenizde ne gibi farklılıklar oldu?" Bu soruya katılımcıların çoğu gıda israfında önceki yıllara göre önemli bir azalmanın olduğunu ve bunları müşterilerin yorumlarında da gördüklerini buna ek olarak da personelin de bu konu da daha hassas ve duyarlı davrandıklarını belirtmişlerdir.

K2, "personelimiz gıda israfi hakkında daha fazla bilgiye sahip oldu".

K3, "misafirlerimiz turuncu bayrak bu uygulamasına sıcak baktıkları için bunları yorumlarında da dile getirdiler ve artık tabaklarına aldıkları yemek miktarına da daha dikkat etmeye başladılar.

\section{Müşterilerde Gıda Atığında Farkındalık Oluşturmaya Yönelik Uygulamalara İlişkin Bulgular}

$\mathrm{Bu}$ başlık altında katılımcılara "işletmenizde misafirlerinizin gıda atığına yönelik farkındalık oluşturmalarını sağlamak için neler yapıyorsunuz? Sorusu yöneltilmiştir. Katılımcılardan alınan cevaplar analiz edilmiş ve şu cevaplara ulaşılmıştır; aldığımız turuncu bayrak uygulamasının 
sahip olduğu logoları özellikle müşterilerin görebilecekleri alanlara yerleştiriyoruz ve belirli aralıklarla müşterilerimize anket yapıp geri dönüşler alıyoruz. Eğer gıda israfına yönelik yaptığımız etkinlikler varsa bunları müşterilerimizle paylaşıyor ve dikkatlerini çekmeye sağlıyoruz. Buna ek olarak da hem uygulama ile ilgili hem de gıda israfı konusunda ki güncel veriler hakkında bilgi veriyoruz.

\section{Müşteri Profilindeki Değişimlere İlişkin Bulgular}

Katılımcılara bu başlık altında "turuncu bayrak uygulaması aldıktan sonra müşterilerinizin algılarında ne gibi değişiklikler oldu" sorusu yöneltilmiştir.

K2, "tesisimiz spor oteli olduğu için otelimize gelen müşterilerimiz zaten yeme-içmelerine dikkat ediyorlar. Belirli porsiyonlarda yemek yedikleri için çok fazla israf söz konusu değil".

K5, "turuncu bayrak uygulaması içerisinde çocuklarla da yapılabilecek etkinlikler olduğu için otelimizi çocuklu aileler de tercih etmeye başlamışlardır".

\section{Personel Seçimine İlişkin Bulgular}

Bu başlık altında katılımcılara "işletmenize personel seçerken gıda atığı konusunda bilinçli olmasına dikkat ediyor musunuz? Personelinizde gıda atı̆̆ 1 konusunda duyarlılı̆̆1 nasıl oluşturuyorsunuz? Soruları yöneltilmiştir. Katılımcılardan alınan cevaplar analiz edilmiş olup şu sonuçlara ulaşılmıştır.

K1, K2, K3 ve K4 "özellikle sezonda işi bilen personel bulmak çok zor bu yüzden bu gibi bir kriterleri çalı̧̧anlarımızda görmek istememiz işletmemizin zararına olacağın düşündüğ̈̈müz için böyle bir özellik aramamaktayız. Ancak işletme bünyesinde çalışmaya başladıktan sonra turuncu bayrak uygulaması sayesinde ğda atığı konusunda çalışanlarımıza seminerler ve eğitimler vererek bu duyarlılığı oluşturmaya çalışıyoruz".

K5 "İşe alırken belki gıda atığı konusunda dikkat etmiyor olabiliriz ancak işe aldıktan sonra oryantasyon sürecinde her türlü atık konusunda bilgilendirme eğitim departmanı tarafindan verilmektedir. Duyarlılık konusunda da yine kurum içi eğitim seminerleri vererek sağlıyoruz".

K6, K8, K9, K10 ve K11, "turuncu bayrak uygulamasını aldıktan sonra çalışanlarımıza 15 günlük bir eğitim veriyoruz ve bu eğitim sonucunda gerçekten gıda israfına duyarlı olan kişilerle çalışmayı tercih ediyoruz".

\section{Gıda Atığı ile İlgili Alınan Önlemlere İlişkin Bulgular}

Katılımcılara “İşletmenizde gıda atığı olarak hangi ürün en çok çöpe gitmektedir? Turuncu bayrak uygulaması bunu ne ölçüde azaltmıştır? Örnek vererek açıklar mısınız?" sorusu yöneltilmiştir. Katılımcıların çoğu en çok ekmek ve sebzenin çöpe gittiğine vurgu yapmışlardır. Gıda atıklarının prosedürlere uygun olarak ayrıştırıldığını ifade etmişlerdir. Otel yöneticileri turuncu bayrak uygulamasını aldıktan sonra gıda atı̆̆ında ciddi ölçüde bir azalmanın olduğunu belirtmişlerdir.

K5, "İ̧letmemizde sıcak yemekler az da olsa artabiliyor. Bunu da bulaşıkhane departmanı uygun kutulara aktarıp atık bölümüne bırakıyorlar. Dediğim gibi turuncu bayrak aldıktan sonra uygulama içerisinde yer alan görsellerle gıda israfinın yapılmaması gerektiğini, tabaklara yiyebilecekleri kadar ürün almaları 
gerektiğini vurgulamış oluyoruz. Bu sayede turuncu bayrak uygulamasının işletmenin maliyetleri azaltma konusunda fayda să̆ladığını söyleyebilirim".

K3, "İsletmemizde az da olsa bir atık söz konusudur. Ancak çıkan atıkları otel bünyesinde bulunan hayvan barınaklarına gönderiyoruz ve kısmen de olsa atığı azaltmış oluyoruz".

\section{Gıda İsrafı ve Gıda Çeşitlerine İlişkin Bulgular}

Bu başlık altında katılımcılara "gelecekte gıda israfı ve diğer israf çeşitleri ile ilgili neler yapmayı planliyorsunuz?" sorusuna şu yanıtları vermişlerdir.

K1, K2 ve K3 "Gıda israfi ve diğger ortaya çıkan tüm israfçeşitleri ile ilgili her yıl turuncu bayrak denetleme yaparak oluşan gıda atığını kontrol altına almaktadır".

K5 ve K6, "Standart tabak ölçülerinden vazgeçip biraz daha küçük ebatlarda olması insanları direk az yemek almaya seok edebilir. Kullanılan görsellerin biraz daha ilgi çekici hale gelmesi için çalışmalar yapılabilir. Ayrıca bilgilendirme kartları hazırlanıp girişlerde misafirlere ek bilgi olarak aktarılabilir.

\section{Gıda İsrafında Farkındalık Uygulamalarına İlişkin Bulgular}

Bu başlık altında katılımcıların tümü gıda israfında farkındalık oluşturabilmek adına müşterilerine anket uygulamaktalar. Bunun yanında ek olarak gıda israfını önlemek için porsiyon küçüklüğüne gidilmekte ve personellere gıda israfı ile ilgili eğitimler verilmektedir.

K1, K5 ve K6, "Müşterilerimize turuncu bayrak uygulaması adı altında anketler uygulamaktayız".

K7, K8, K11, “Gıda israfin önlemek adına yapabileceğimiz ilk şey porsiyon seçenekleri sunarak gıda atığı en aza indirilebilir".

Alınan cevaplar doğrultusunda turuncu bayrak uygulamasına sahip otellerin hem sertifikasyon programlarının devamını sağlayabilmek hem de müşterileri gözünde gıda atığı konusunda farkındalık oluşturabilmeleri için yapmış oldukları uygulamaların olduğu sonucuna varılmıştır. Turuncu bayrak uygulamasına sahip oteller sadece müşterilerine değil personellerine de gıda atığı konusunda bilinçlenmeleri için eğitim verilmektedir.

\section{SONUÇ VE ÖNERİLER}

İşletmelerin kârlılığını ve varlığını sürdürülebilir kılmak için çevreye uyumlu uygulamalar yapması kaçınılmaz olmuştur. Bilinçli tüketiciyi işletmeye çekmek ve çektikten sonra işletme bünyesinde tutabilmek için yeşil veya sürdürülebilir adı altında çevreci uygulamalara ya da sertifikalara sahip olmaları gerekmektedir. Özellikle konaklama işletmelerindeki gıda atıklarının geri dönüşümünün sağlanması işletmelerde oluşan israfı hem de gider kalemlerini azaltarak işletmeye katkı sağlamaktadır. Konaklama işletmelerindeki özellikle mutfak bölümündeki çöpe gitmeyen her ürün işletmenin giderini azaltmaktadır.

Turuncu bayrak uygulamasının hem çevreci hem de gıda israfını engelleyici özelliğinin olması işletmeler açısından önem arz etmektedir. İlk olarak otel işletmelerine verilmeye başlayan turuncu bayrak uygulaması daha sonra hem restoranlara hem diğer kuruluşlara verilebilmektedir. Turuncu bayrak uygulamasına sahip olan otel işletmeleri yapıları itibariyle normal bir otelin ötesinde farkındalık anlayışına sahip olmaktadırlar. Turuncu bayrak uygulamasına sahip otellerin amaçları sadece gelen müşterilerine konaklama hizmeti sunmak 
değil bunu yaparken de gıda atığını en aza indirmektir. Türkiye'de uygulamaya başlanan turuncu bayrak uygulamasına konaklama işletmelerinden yeteri kadar ilgi olmamıştır.

Araştırma sonuçlarından en önemlilerinden bir tanesi olarak turuncu bayrak uygulamasına sahip otellerin gıda israfını azaltıı bir etkisi olduğuna ve gıda israfı konusunda duyarlı olan müşterileri otele çekmeleri konusunda etkili olduğu sonucuna varılmıştır. Araştırmanın bir diğer sonucu ise, turuncu bayrak uygulamasını oteller alırken zaman, maliyet gibi sorunlar yaşamadıklarını ancak bu uygulamayı almakla işlerinin bitmediğini bunun devamlılı̆̆ını sağlamaları gerektiği sonucuna varılmıştır.

Turuncu bayrak uygulamasını oteller aldıktan sonra nelerin değiştiği sorusuna alınan cevaplar doğrultusunda katılımcılardan personelin gıda atığı konusunda bilgilenip ona göre davrandığını müssterilerin ise bu uygulama sayesinde yiyecek alımında daha dikkatli davrandıkları sonucuna varılmıştır. Turuncu bayrak uygulamasına sahip otellerin personellerinin ve müşterilerinin gıda atığı konusunda daha bilinçli davrandıkları sonucuna varılmıştır.

Katılımcılardan alınan cevaplar doğrultusunda müşterilerde gıda atığı farkındalıklarını oluşturmak için yaptıkları uygulamalarda turuncu bayrak uygulamasına ait logo ve uyarıcı levhaların önemli bir etkisi olduğu sonucuna varılmıştır.

Araştırma kapsamında otellerin turuncu bayrak uygulamasını aldıktan sonra müşteri profilinde de önemli değişiklikler yaşanmıştır. Özellikle turuncu bayrak uygulamasında çocuklara yönelik gıda israfı ile ilgili etkinliklerinden olması çocukla aileleri de bu otellere çekmeyi başardığı sonucuna varılmıştır. Katılımcılardan alınan cevaplar doğrultusunda ulaşılan diğer bir sonuç ise personel seçiminde gıda atığı konusunda duyarlı olup olmadıklarının bir kriter olarak personel alımlarında sorulamadığını ancak personele işletme bünyesine alındıktan sonra her türlü gıda atığı ile ilgili eğitimler verilerek bilinçlendirildiği sonucuna varılmıştır.

Katılımcılardan alınan cevaplar doğrultusunda gıda atığını önlemek adına aldıkları önlemler arasında tabak boyutlarını küçülterek misafirlerin yiyebilecekleri kadar yemek almalarını sağlamalarıdır. Buna ek olarak turuncu bayrak uygulaması kapsamında misafirlere anketler uygulandığını gıda atığı konusunda bilgilendirme yapıldığı sonucuna varılmıştır.

Yöneticiler gözünde turuncu bayrak uygulaması oteller turuncu bayrak uygulamasını aldıktan sonra gıda atı̆̆ında önemli bir azalma gözlemlemişlerdir. 2019 yılında elde edilen verilere göre turuncu bayrak uygulaması ile 3 milyon turistin gıda israfına karşı farkındalıkları oluşturularak açık büfelerdeki israf azaltılmıştır. Bunun yanı sıra turuncu bayrak uygulaması ile 3500 turizm personeline verilen eğitimlerle gıda israfına karşı duyarlı olmaları sağlanmıştır. 2020 yılında turuncu bayrak uygulamasına sahip olacak otel sayısının 120 olması, 10 bin duyarlı turizm personeli ve 20 milyon tatilci sayısına ulaşmak planlanmaktadır.

Otel yöneticilerinin verdikleri cevaplar doğrultusunda turuncu bayrak uygulamasını aldıktan sonra hem diğer otellere göre bir adım önde oldukları sonucuna varılmıştır. Bunun yanı sıra turuncu bayrak uygulamasını aldıktan sonra gıda israfında önemli bir azalma görülmüştür. Turuncu bayrak uygulamasına sahip olduktan sonra gida israfı ve diğer israf konularında daha duyarlı davrandıkları sonucuna varılmıştır.

Turuncu bayrak uygulamasında yer alan müşterilerin gıda israfında farkındalık oluşturarak dikkatini çekmek adına oluşturulan logolar ve açık büfe sistemi uygulayan otellerin porsiyon küçültmeye gitmelerinde olumlu sonuçlar elde edilmiştir.

Araştırma konusu yeni çalışılmaya başlayan bir konu olduğu için ilerleyen çalışmalarda daha geniş çaplı çalışmalar yapılarak alan yazına daha çok katkı sağlanabilir. Özellikle turuncu bayrak uygulamasının beş yıldızlı otellerin restoranlarına ya da farklı konseptler deki her şey dâhil 
sistem otellerine uygulanarak gıda atığının engellenebileceği konusunda farkındalık oluşturulabileceği düşünülmektedir.

Otel işletmelerinde ortaya çıkan gıda atığının (ekmek) önüne geçmek adına yapılması gerekenler (Mete, 2017: 4);

$>$ Ekmekler bayatlamaması için doğru saklama koşullarında ambalajlanmalıdır,

> Eğer ekmekler uzun süre saklanması gerekiyorsa, poşetlenerek derin dondurucuda saklanmalıdır.

$>$ Ekmekler tüketilmeden önce dilimlenerek servis edilmelidir.

$>$ Kurumuş ekmekler çöpe atılmadan önce nasıl değerlendirilebilir konusunda araştırmalar yapılmalıdır. Kurumuş ekmekler galeta unu, kıtır ekmek, pasta ve tatlı yapımında değerlendirilmelidir.

$>$ Ekmek günlük ihtiyaca göre ne kadar tüketilecekse o kadar alınmasına dikkat edilmelidir (Kavak, 2010: 15).

\section{KAYNAKÇA}

Akın, O. (2010). Ekmek Üretim İşletme Sahiplerinin Profilleri ve Sektöre Yönelik Tutumları: Batı Akdeniz Bölgesinde Bir Araştırma. Süleyman Demirel Üniversitesi Vizyoner Dergisi. 2(1), 157-168.

Akkoç, A. (2017). Tüketim Toplumu ve Sürdürülebilirlik. ProceedingsBook of 2nd International Scientific Researches Congress on Humanities and Social Sciences. 583-587.

Aschemann-Witzel, J., de Hooge, I., Amani, P., Bech-Larsen, T., and Oostindjer, M. (2015). Consumer-related food waste: Causes and potential for action. Sustainability, 7(6), 6457-6477.

Bolayır, B. ve Ergülen, A. (2017). Bulanık doğrusal programlama yöntemi ile optimal planlama: gıda ve tarım ürünleri atıklarından geri dönüşüm yapan bir işletmede uygulama. Ulakbilge Sosyal Bilimler Dergisi, 5(18), 2097-2129.

Coşkun, M. (2012). Popüler Kültür ve Tüketim Toplumu. Batman Üniversitesi Yaşam Bilimleri Dergisi. 1(1), 837-850.

Çam, M. (2009). Konaklama işletmelerinde yiyecek-içecek maliyet kontrolünün önemi ve Akdeniz bölgesindeki konaklama işletmelerinde bir anket çalışması. Mustafa Kemal Üniversitesi Sosyal Bilimler Enstitüsü Dergisi, 6(11), 502-524.

Doğdubay, M. (2006). Büyük Ölçekli Otellerdeki Yiyecek-İçecek Departmanlarının Üretim Kayıplarını Önlemeye Yönelik Olarak Üretim Planlaması ve Kontrol Sistemlerinin Uygulanabilirliği (Karşılaştırmalı Bir Uygulama), Yayımlanmamış Doktora Tezi, Balıkesir Üniversitesi Sosyal Bilimler Enstitüsü, Balıkesir.

Doğdubay, M. ve Sarığlan, M. (2010). Büyük ölçekli otel işletmelerinin yiyecek-içecek ünitelerinde üretim dengesini bozan üretim kayıplarının rapor edilmesi. Türk Bilim Araştırma Vakfi, 3(1), 106-116.

Dölekoğlu, C., Ö., Gün, S. ve Giray, F., H. (2014). Yoksulluk ve Gıda İsrafı Sarmalı. XI. Tarım Ekonomisi Kongresi Bildiri Kitabı 3-5 Eylül. 172-191.

Erik, U. (2019). Restoran işletmelerinde gıda israfının önlenmesi ve ihtiyaç fazlası yemeğin değerlendirilmesine yönelik bir mobil uygulama modelinin geliştirilmesi: LUSE, 
Yayımlanmamış Yüksek Lisans Tezi, Necmettin Erbakan Üniversitesi, Sosyal Bilimler Enstitüsü, Konya.

Gjerris, M. and Gaiani, S., (2013). Household food waste in Nordic countries: Estimations and ethical implications. Nordic Journal of Applied Ethics 7(1): 6-23.

Güler, A., Halıcıoğlu, M.B. ve Taşğın, Y. (2015). Sosyal Bilimlerde Araştırma Yöntemleri, Seçkin Yayıncilık: Ankara.

Gümrük ve Ticaret Bakanlığı, (2019). Türkiye İsraf Raporu 2019, www.Tuketici.Gtb.gov.tr (Erişim Tarihi, 25.11.2019).

Gümüş, Ç. (2014). Ekmek İsrafını Önleme Konulu Sosyal Sorumluluk Kampanyasına İlişkin Akademisyen, Uzman ve Öğrenci Görüşleri, Yayımlanmamış Doktora Tezi, Gazi Üniversitesi, Eğitim Bilimleri Enstitüsü, Ankara.

İlyasof, A. (2017). Türk Misafirlerin Gıda İsrafı Tutumları Üzerine Beş Yıldızlı Otel İşletmelerinde Bir Araştırma: Alanya Örneği, Yayımlanmamış Yüksek Lisans Tezi, Süleyman Demirel Üniversitesi.

Karagöz, Y. (2017). SPPS ve AMOS Uygulamah Nitelik-Nicelik-Karma Bilimsel Araştırma Yöntemleri ve Yayın Etiği, Nobel Akademik Yayıncllık: İstanbul.

Karasar, N. (2005). Bilimsel Araştırma Yöntemi, Nobel Yayıncılık: Ankara.

Kavak, A. (2010). Türkiye'de ve Dünyada Ekmek Sanayi. Gıda, Tarım ve Hayvancılık Bakanlığı Gida ve Kontrol Genel Müdürlüğü.

Kayhan, V. (2006). Kurân'a göre israf ve İktisat. Din Bilimleri Akademik Araştırma Dergisi, 6(3), 149195.

Kurt, Y. (2019). Yiyecek-İçecek Personelinin Gıda İsrafı Hakkında Bilgi, Görüş ve Davranışları: Eskişehir İli Örneği, Yayımlanmamış Yüksek Lisans Tezi, Gazi Üniversitesi, Sosyal Bilimler Enstitüsü, Ankara.

Martı, H. (2010). Tüketim: Hayatin Amacı Değil, Anlam Döngüsünün Aracı. Tüketim Ve Değerler, İstanbul Ticaret Odası Yayını, 139.

Mete, H. (2017). Ekmek İsrafı ve Önleme Yöntemleri. Tekirdağ SMMM Odası Sosyal Bilimler Dergisi. 7, 1-10.

Özdal, E. (2015). Hadisler' de İsraf ve İktisat, Harran Üniversitesi, Yayımlanmamış Yüksek Lisans Tezi, Sosyal Bilimler Enstitüsü, Şanlıurfa.

Özdemir, G. (2018). Food Waste Management Within Sustainability Perspective: A Study on Five Star Chain Hotels, Yayımlanmamış Doktora Tezi, Gazi Üniversitesi, Sosyal Bilimler Enstitüsü, Ankara.

Papargyropoulou, E., Lozano, R., Steinberger, J. K., Wright, N., and bin Ujang, Z. (2014). The food waste hierarchy as a framework for the management of food surplus and food waste. Journal of Cleaner Production, 76, 106-115.

Pekcan, R. (2019). Türkiye İsraf Raporu, 31-01-2019\%20ISRAF\%20RAPORU.pdf, (Erişim Tarihi, 26.11.2019).

Sancaklı, S. (2013). Hadisler Çerçevesinde İsraf Olgusunun Analizi. İnönü Üniversitesi İlahiyat Fakültesi Dergisi, 4 (1), 1-25.

TDK, (2019). https://sozluk.gov.tr/?kelime=\%C4\%B0SRAF, (Erişim Tarihi, 23.11.2019). 
TMO, (2019). www.ekmekisrafetme.com/Pages/GenelBilgiler/DunyadaIsraf.aspx, (Erişim Tarihi, 25.11.2019).

Turuncu Bayrak Kriterleri,(2019). turuncubayrak.org. (Erişim Tarihi: 26.11.2019).

Turuncu Bayrak Nedir? (2019), turuncubayrak.org. (Erişim Tarihi: 26.11.2019).

UNWTO, (2019). International Tourism Highlights, https://www.eunwto.org/doi/pdf/10.18111/9789284421152, (Erişim Tarihi, 18.04.2020).

Yıldırım, A. ve Şimşek, H. (2016). Nitel Araştırma Yöntemleri, Seçkin Yayıncılık: Ankara.

Yıldırım, E. (2019). Türkiye'de Helal Konseptli Otel İşletmelerinde İsrafın Değerlendirilmesi, Yayımlanmamış Yüksek Lisans Tezi, Gaziantep Üniversitesi, Sosyal Bilimler Enstitüsü, Gaziantep. 